\title{
Characterization of Egyptian Moringa oleifera Lipids (Whole Seeds and Kernels) Salama, M. A. ${ }^{1}$; M. A. Owon ${ }^{2}$; M. F. Osman ${ }^{2}$ Awatif I. Esmail $^{1}$ and B. Matthäus ${ }^{3}$ \\ ${ }^{1}$ Food Technology Research Institute, Agriculture Research Center, Egypt. \\ ${ }^{2}$ Food Technology Department, Faculty of Agriculture, Kafrelsheikh University, Egypt. \\ ${ }^{3}$ Max Rubner-Institut (MRI) Bundesforschungsinstitut für Ernährung und Lebensmittel, Institut für Sicherheit und Qualität bei GetreideSchützenberg, Detmold, Germany
}

\section{ABSTRACT}

Moringa seeds (Moringa oleifera) are rich in oil contents, the purpose of this study is to extract the oil from the whole seeds and kernels of the Egyptian Moringa by cold and hot extraction methods and to study the effect of extraction method on the composition of fatty acids, tocopherols and triglycerides in extracted oil. The results indicated that the amount of extracted oil by hot extraction were $28.85 \%$ and $39.23 \%$ and by cold extraction were $21.39 \%$ and $29.34 \%$ for whole seeds and kernels, respectively. The main saturated and unsaturated fatty acids in both were behenic $(6.76-6.49 \%)$ and oleic $(66.22-65.78 \%)$ acids. Palmitic acid was higher in the kernels than in the whole seeds $(5.90-5.55 \%)$, while vaccenic acid was higher in the whole seeds than in the kernels $(6.33-6.15 \%)$, respectively. After cold extraction, stearic and behenic acids increased in whole seeds (4.55 to 5.51\%), (6.76 to 7.67\%) and kernels (4.45 to $5.52 \%),(6.49$ to $7.85 \%)$, respectively. While, oleic, vaccenic, linoleic and gondoic acids decreased by cold extraction in whole seeds and kernels. Tocopherols obtained from kernels were more than whole seeds. $\alpha$-Tocopherol by hot extraction in the kernels and the whole seeds was 20.92 and $14.61 \mathrm{mg} / 100 \mathrm{~g}$, respectively. Using cold extraction in kernels caused significant decrease in $\alpha$-Tocopherol $(20.92-16.82 \mathrm{mg} / 100 \mathrm{~g})$. A significant difference appeared between whole seeds and kernels in the triglycerides (2,3-dioleyl-1palmitoylglycerol) "POO" (15.64\% and 15.86\%) and (1,2,3 trioleylglycerol) "OOO" (34.22 and 34.32\%). After cold extraction in both, triglycerides (1,3-distearoyl-2-oleylglycerol) "SOS" and (2,3-dioleyl-1- stearoyl) "SOO" increased (1.77 - 2.17\% and 9.82 - 11.25\% whole seeds) and ( $1.80-2.07 \%$ and $9.86-11.38 \%$ kernels $)$.

Keywords: Moringa oleifera, Oil extraction, Fatty acids, Tocopherols, triglycerides.

\section{INTRODUCTION}

Moringa oleifera is a member of family Moringaceae. It is the most famous and utilized species in this family (Morton, 1991). It is wide spread in the western and sub-Himalayan tracts, India, pakistain, Africa (Mughal et al., 1999). Also it is found in central America, Caribbean Islands and North and South of America (Morton, 1991).

It has many traditional names such as horseradish or drumstick. In Egypt they called it "Shagara al Rauwaq" the tree of purification (Von, 1986). Due to its coagulating properties, it is used for water purification (Kalogo et al., 2000; Anwar et al., 2007). The shape of the seeds is triangle or round. These seeds are present inside pods. The kernels surrounded by coat which is easy to remove (Abdulkarim et al., 2005). 400 - 1000 pods and $15000-$ 25000 seeds could be taken from each tree per year. The ratio of the kernels to the coat is $75-25 \%$ (Jahn, 1988).

Moringa oleifera considers as a vegetable food in some countries (Siddhuraju and Becker, 2003). The young pods are eaten in Indonesia like vegetables and it taste like asparagus (TANCN, 2003). The fried seeds have a taste like peanuts (Qaiser, 1973). The leaves are used by Philippine women mixed with chicken or shellfish soup to increase the production of milk for women (Siddhuraju and Becker, 2003). Oduro et al., (2008) reported that the leaves contained a good amount of iron and calcium. Also, it can be used as an external application for wounds (The Wealth of India, 1962). Sodamade et al., (2013); Gowrishankar et al., (2010) reported that the leaves were a good source of $\mathrm{Na}, \mathrm{Fe}, \mathrm{Cu}, \mathrm{Zn}$ and $\mathrm{Mg}$. Marrufo et al., (2013) reported that Moringa oleifera leaves contained essential oil which had antimicrobial activities

Many parts of Moringa tree contain a good amount of amino acids - especially essential amino acids (Amagloh and Benang, 2009). Moringa oleifera root, seeds and leaf protein are characterized of good quality and as such are suitable for animal feeds and human diets (Okereke and Akaninwor, 2013). Anwar et al., (2007) reported that Moringa is an important source of minerals, protein, vitamins, phenolic compounds and beta-carotene.

All parts of this tree have medicinal properties. The Wealth of India, (1962) and Dahot, (1988) reported that it can be used in the treatment of rheumatism, venomous bites and ascites. Also, it has an effect as antiepileptic, antipyretic, anti-inflammatory, antiulcer effects and antitumor (Cáceres et al., 1992; Singh and Kumar 1999; Morimitsu et al., 2000; Siddhuraju and Becker, 2003).

Ben oil the common name of the oil extracted from Moringa contains high amount of oleic acid. As known mono unsaturated fatty acids (oleic acid) has more oxidative stability than polyunsaturated fatty acids at frying processes and storage. Moringa oil (Ben oil) has more stability during frying than canola, soybean and palm olein oils (Abdulkarim et al., 2007). It smells like peanut (Kleiman et al., 2008). All the main fatty acids in olive oil are found in moringa oil, so it can be used as an alternative to olive oil after some modification (Dahot and Memon, 1985). Tsaknis et al., (1999) said that Moringa oil was used in making perfume and products for hair protection. The most prominent polyunsaturated triglycerides (TAG) in Moringa oil was triolein "OOO" 36.7\% (Abdulkarim et al., 2005). Several studies used different methods to extract Moringa oil. Abdulkarim et al., (2005) used hot extraction with different solvents and aqueous enzymatic methods. They found the oil amount extracted by solvent was higher than enzymatic methods. Oleic acid was higher in enzymatic methods than in the solvents $(70.00-67.90 \%)$. Other study (Tsaknis et al., 1999) extracted the oil from Moringa seeds using three different procedures including cold press, extraction with n-hexane and extraction with a mixture of chloroform/methanol (50:50). Using hexane extracted the highest amount of the oil was $35.70 \%$. Oleic acid by using cold press reached to $75.39 \%$ followed by $73.91 \%$ by chloroform/methanol (50:50). The properties and the content of the oil can be changed and this may be due to the environmental condition and the species (Ibrahim et al., 1974). 
This research aims to study the difference between the oil extracted from Moringa oleifera whole seeds and kernels by two methods "hot and cold extraction" by studying fatty acids, tocopherols and triglycerides.

\section{MATERIALS AND METHODS}

\section{Materials:}

The materials used in this investigation were Moringa oleifera seeds. These seeds were purchased from Agriculture research center, Sakha, Kafrelsheikh City, Egypt.

Preparation of Moringa oleifera for analysis:

Mature Moringa oleifera dried pods were collected from Agriculture research center - Sakha - KafrelsheikhEgypt. The pods were opened to collect the seeds from inside. The seeds were dried in the sun. After that the seeds were divided to two portions. The first one we grinded it with the coat, this one called "Whole seeds". The second one the coat was removed from the seeds before grinding and called it "Kernels".

\section{Chemicals:}

Petroleum ether (40-60) was of analytical grade (>98\%; Merck, Darmstadt, Germany). Heptane and tertbutyl methyl ether were of HPLC grade (Merck, Darmstadt, Germany). Tocopherol, tocotrienol standard compounds and Folin-Ciocalteau reagent were purchased from, Merck, (Darmstadt, Germany). Standards fatty acids methyl esters were obtained from, Restek, (Bad Homburg, Germany). Beta carotene was obtained from (Fluka, Germany).

\section{Methods}

\section{Chemical composition}

The methods of the Association of Official Analytical Chemists (AOAC, 2010) were used for proximate analysis.

\section{Oil extraction:}

The oil content was determined according to method DGF-B-I-5, (2013) by hot extraction using a Twisselmann apparatus. In brief, five gram of the dried seeds were grinded in a mill (IKA, model A11 BS000, Germany) and extracted using $75 \mathrm{~mL}$ petroleum ether in a Twisselmann apparatus for $6 \mathrm{hrs}$. For cold extraction, $20 \mathrm{~g}$ from the seeds were soaked in $200 \mathrm{ml}$ of petroleum ether for 48 hours at room temperature. The obtained solvent from hot and cold extraction methods was removed by a rotary evaporator at $40^{\circ} \mathrm{C}$ and 25 Torr (model RV $10 \mathrm{C} \mathrm{S} 93$, IKA-Werke GmbH \& Co. KG, Stauffen, Germany). For the determination of fatty acids, tocopherols and triacylglycerols the oil was dried by a stream of nitrogen after removing the solvent by a rotary evaporator to avoid the formation of degradation products during drying in the oven.

\section{Fatty acids composition:}

The fatty acids composition were determined following the DGF-C-VI 10, (2013) in combination with DGF-C-VI 11d, (2013). The prepared sample was injected in a HP5890 gas chromotograph (Agilent Technologies Sales \& Services GmbH \& Co. KG, Waldbronn, Germany), with a capillary column, CP-Sil 88 (100 m long, $0.25 \mathrm{~mm} \mathrm{ID}$, film thickness $0.2 \mu \mathrm{m}$ ). The temperature program was as follows: From $155^{\circ} \mathrm{C}$; heated to $220{ }^{\circ} \mathrm{C}$ $\left(1.5^{\circ} \mathrm{C} / \mathrm{min}\right), 10 \mathrm{~min}$ isotherm; injector $250{ }^{\circ} \mathrm{C}$, detector $250{ }^{\circ} \mathrm{C}$; carrier gas $36 \mathrm{~cm} / \mathrm{s}$ hydrogen; split ratio 1:50; detector gas $30 \mathrm{~mL} / \mathrm{min}$ hydrogen; $300 \mathrm{~mL} / \mathrm{min}$ air and 30
$\mathrm{mL} / \mathrm{min}$ nitrogen; manual injection volume less than $1 \mu \mathrm{L}$. The peak areas were computed by the integration software, and percentages of fatty acid methyl esters (FAME) were obtained as weight percent by direct internal normalization.

\section{Tocopherols composition:}

Tocopherols composition (tocopherols, tocotrienols and plastochromanol-8) were determined according to method DGF-F-II 4a, (2013). $20 \mu \mathrm{L}$ from the sample were injected by a Merck 655-A40 autosampler (Merck-Hitachi, Darmstadt, Germany) onto a Diol phase HPLC column 25 $\mathrm{cm} \times 4.6 \mathrm{~mm}$ ID (Merck, Darmstadt, Germany) with a flow rate of $1.3 \mathrm{~mL} / \mathrm{min}$. The mobile phase was $\mathrm{n}$-heptane and tert-butyl methyl ether

Triglycerides composition:

The triacylglycerol composition was determined by gas chromatography according to method DGF-C-VI 14, (2013).

\section{Statistical analysis:}

The data were statistically analyzed by paired samples $\mathrm{T}$ test analysis of variance (ANOVA) procedure with SPSS software (Version 16.0, SPSS Inc., Chicago, IL) software (Steel and Torrie, 1980).

3. Results and discussion

\section{Chemical composition:}

From Tables (1 and 2), the kernels of Moringa oleifera had more amount of protein $(40.18 \%)$ and ether extract $(39.23 \%)$ by hot extraction than the whole seeds were $(31.30 \%)$ and $(28.85 \%)$, respectively. While by cold extraction the oil amount was $21.39 \%-29.34 \%$ from the whole seeds and kernels, respectively.

Ash, fibers and carbohydrates were higher in the whole seeds $(4.22 \%, 26.71 \%$ and $8.92 \%)$ than the kernels $(4.04 \%, 13.96 \%$ and $2.59 \%)$, respectively. This is due to the presence of the coat with the whole seeds.

This finding is nearly similar with Abiodun et al., (2012) and Rahman et al., (2009) they reported that the moisture, protein and ash from the whole seeds were $(4.70-$ $7.10 \%),(28.04-31.80 \%)$ and $(4.10-6.30 \%)$, respectively. Also, Anwar and Bhangers, (2003) and Compaoré et al., (2011) reported that the protein was $29.36 \%$ and $35.37 \%$ in the kernels of Moringa olifera.

Table 1. Chemical composition of Moringa oleifera (whole seeds and kernels) (on dry weight basis):

\begin{tabular}{lcc}
\hline \multirow{2}{*}{ Composition } & \multicolumn{2}{c}{ Moringa oleifera } \\
\cline { 2 - 3 } & Whole seeds (\%) & Kernels (\%) \\
\hline Moisture & 6.70 & 5.90 \\
Protein & 31.30 & 40.18 \\
Ether extract* & 28.85 & 39.23 \\
Ash & 4.22 & 4.04 \\
Fibers & 26.71 & 13.96 \\
Carbohydrates & 8.92 & 2.58 \\
\hline
\end{tabular}

*Hot extraction

Table 2. Effect of extraction methods on the oil amount of Moringa oleifera:

\begin{tabular}{lcc}
\hline Extraction & \multicolumn{2}{c}{ Moringa oleifera } \\
\cline { 2 - 3 } methods & Whole seeds (\%) & Kernels (\%) \\
\hline Hot & $28.85 \pm 1.708$ & $39.23 \pm 1.758$ \\
Cold & $21.39 \pm 1.346$ & $29.34 \pm 1.180$ \\
\hline
\end{tabular}

The results of the oil amount are in agreement with the results obtained by Bhutada et al., (2016) who reported that the oil yield from Moringa whole seeds using petroleum ether (hot extraction) was $28.60 \%$. According to 
Kibazohi and Sangwan, (2011), the oil was (24.80\%) using hexane (hot extraction) from the Moringa whole seeds. While from Moringa kernels, Rahman et al., (2009) reported that the oil amount was $(35.60 \%)$ using petroleum ether and $(37.50 \%)$ using hexane (hot extraction). Also, Anwar and Rashid, (2007) and Da Porto et al., (2016) used hexane (hot extraction) and found the amount from Moringa kernels were $34.80 \%$ and $36.33 \%$, respectively. Extraction method and solvent used, climate, time of harvest and plant variety are reasons for the difference in the amount of extracted oil (Abdulkarim et al., 2005).

\section{Fatty acids composition:}

Table (3) showed that the oil extracted by hot extraction in Moringa whole seeds and kernels contained palmitic acid $(5.55 \%$ and $5.90 \%)$, respectively. While by using cold extraction stearic was $(5.51 \%-5.52 \%)$ and behenic acid was $(7.76 \%-7.85 \%)$ in Moringa whole seeds and kernels, respectively.

The content of the extracted oil by cold extraction for saturated fatty acids was $23.43 \%$ and $23.68 \%$, respectively for whole seeds and kernels. While in the case of hot extraction the content of saturated fatty acids was $21.80 \%$ and $21.64 \%$, respectively for both whole seeds and kernels. The content of unsaturated fatty acids was $75.15 \%$ - $75.42 \%$ by using cold extraction in whole seeds and kernels and was $77.54 \%-76.81 \%$ in whole seeds and kernels, respectively (Table 3 ).

Table 3. Fatty acids composition of Moringa oleifera (whole seeds and kernels ) by hot and cold extraction (\%):

\begin{tabular}{|c|c|c|c|c|}
\hline \multirow{3}{*}{ Fatty acids } & \multicolumn{4}{|c|}{ Moringa oleifera } \\
\hline & \multicolumn{2}{|c|}{ Whole seeds } & \multicolumn{2}{|c|}{ Kernels } \\
\hline & Hot & Cold & Hot & Cold \\
\hline Myristic $C_{14 \cdot 0}$ & $0.12 \pm 0.021 *$ & $0.09 \pm 0.006$ & $0.15 \pm 0.023^{* 0}$ & $0.09 \pm 0.000^{6}$ \\
\hline Palmitic $\mathrm{C}_{16: 0}$ & $5.55 \pm 0.255^{*}$ & $5.15 \pm 0.046$ & $5.90 \pm 0.139 * \mathrm{~b}$ & $5.16 \pm 0.030^{\mathrm{b}}$ \\
\hline Margaric $\mathrm{C}_{17: 0}$ & $0.08 \pm 0.012$ & $0.09 \pm 0.000$ & $0.08 \pm 0.010$ & $0.08 \pm 0.006$ \\
\hline Stearic $\mathrm{C}_{18: 0}$ & $4.55 \pm 0.066^{\mathrm{a}}$ & $5.51 \pm 0.066^{\mathrm{a}}$ & $4.45 \pm 0.112^{\mathrm{b}}$ & $5.52 \pm 0.010^{\mathrm{b}}$ \\
\hline Arachidic $\mathrm{C}_{20: 0}$ & $3.35 \pm 0.119$ & $3.63 \pm 0.036$ & $3.21 \pm 0.046^{\mathrm{b}}$ & $3.72 \pm 0.020^{\mathrm{b}}$ \\
\hline Behenic $\mathrm{C}_{22: 0}$ & $6.76 \pm 0.419^{a}$ & $7.67 \pm 0.139^{\mathrm{a}}$ & $6.49 \pm 0.082^{\mathrm{b}}$ & $7.85 \pm 0.030^{\mathrm{b}}$ \\
\hline Lignoceric $\mathrm{C}_{24: 0}$ & $1.39 \pm 0.060$ & $1.29 \pm 0.015$ & $1.36 \pm 0.023^{\mathrm{b}}$ & $1.26 \pm 0.006^{\mathrm{b}}$ \\
\hline TSFA & 21.80 & 23.43 & 21.64 & 23.68 \\
\hline Palmitoleic $\mathrm{C}_{16: 1 \text { cis }}$ & $1.42 \pm 0.066$ & $1.36 \pm 0.006$ & $1.42 \pm 0.040$ & $1.43 \pm 0.015$ \\
\hline Elaidic $\mathrm{C}_{18: 1 \mathrm{D} 9 \mathrm{tr}}$ & $0.24 \pm 0.050^{\mathrm{a}}$ & $0.16 \pm 0.020^{\mathrm{a}}$ & $0.26 \pm 0.029^{b}$ & $0.37 \pm 0.000^{\mathrm{b}}$ \\
\hline Oleic $\mathrm{C}_{18: 1 \mathrm{D} 9}$ cis & $66.22 \pm 0.172^{\mathrm{a}}$ & $65.16 \pm 0.016^{\mathrm{a}}$ & $65.78 \pm 1.054$ & $64.84 \pm 0.172$ \\
\hline Vaccenic $\mathrm{C}_{18: 1 \mathrm{D} 11 \mathrm{tr}}$ & $6.33 \pm 0.031{ }^{* a}$ & $5.78 \pm 0.010^{\mathrm{a}}$ & $6.15 \pm 0.045^{* \mathrm{~b}}$ & $6.07 \pm 0.015^{\mathrm{b}}$ \\
\hline Linoleic $\mathrm{C}_{18: 2 \mathrm{D}} \mathrm{D}, 12$ cis & $0.63 \pm 0.006^{\mathrm{a}}$ & $0.56 \pm 0.010^{\mathrm{a}}$ & $0.62 \pm 0.010^{\mathrm{b}}$ & $0.55 \pm 0.006^{\mathrm{b}}$ \\
\hline Linolenic $\mathrm{C}_{18: 3} \mathrm{D}_{9.12 .15 \text { cis }}$ & $0.18 \pm 0.032$ & $0.16 \pm 0.000$ & $0.17 \pm 0.000$ & $0.16 \pm 0.006$ \\
\hline Gondoic $\mathrm{C}_{20: 1} \mathrm{D} 11$ cis & $2.37 \pm 0.075^{\mathrm{a}}$ & $1.88 \pm 0.025^{\mathrm{a}}$ & $2.29 \pm 0.012^{\mathrm{b}}$ & $1.91 \pm 0.010^{\mathrm{b}}$ \\
\hline Erucic $\mathrm{C}_{22: 1} \mathrm{D} 13$ cis & $0.15 \pm 0.029$ & $0.09 \pm 0.006$ & $0.12 \pm 0.015$ & $0.09 \pm 0.000$ \\
\hline TUSFA & 77.54 & 75.15 & 76.81 & 75.42 \\
\hline The sum & 99.34 & 98.58 & 98.45 & 99.10 \\
\hline
\end{tabular}

(*) Means that there are significant differences between whole seeds and kernels (hot extraction) at $\leq \mathbf{0 . 0 5}$.

(a) Means that there are significant differences between whole seeds (hot and cold extraction) at $\leq 0.05$.

(b) Means that there are significant differences between kernels (hot and cold extraction) at $\leq 0.05$.

Moringa oleifera whole seeds and kernels contained a good amount of behenic acid (6.76-6.49\%), respectively. Behenic acid using hot extraction of whole seeds and kernels $(6.76-7.67 \%)$ increased in cold extraction of kernels (7.85\%) and whole seeds (7.67\%). Behenic acid result was similar to the once which reported by Abdulkarim et al., (2005), Rashid et al., (2008) and Nguyen et al., (2011) which reached $(5.80 \%),(7.00 \%),(7.01 \%)$ and $(6.71 \%)$, respectively. In skincare, behenic acid is most commonly used to provide soothing relief for dry and sensitive skin (Banov et al., 2014). The obtained results of vaccenic acid was in similar to the result reported Al Juhaimi et al., (2016)
Using cold extraction caused a slight decrease in palmitic acid in whole seeds and kernels, it reached to $5.15 \%$ and $5.16 \%$, respectively. Also, the same effect had happened in the unsaturated fatty acid gondoic $(1.88 \%-1.91 \%)$, respectively. While an increased had happened in stearic acid in both. No significant differences appeared in margric acid between whole seeds and kernels also by using hot and cold extraction. Between the oil extracted from whole seeds and kernels by hot extraction a differences had appeared in myristic, plamitic and vaccenic acids. Myristic and plamitic were higher in kernels than whole seeds $(0.12-0.15 \%)$, $(5.55-5.90 \%)$, respectively, while vaccenic was high in whole seeds $(6.33-6.15 \%)$ (Table 3$)$

Also the results in Table (3) showed that the content of oleic acid from the oil extracted by hot extraction was $66.22 \%$ and $65.78 \%$ in whole seeds and kernels, respectively and vaccenic acid was $6.33 \%$ and $6.15 \%$ in both in comparison with cold extraction. This high amount of oleic acids makes Moringa oil preferable in nutrition and cooking (Abdulkarim et al., 2005). Also, it be used in frying due to its oxidative stability (Petukhov et al., 1999). This finding is in agreement with the results obtained by Abdulkarim et al., (2005), Nzikou et al., (2009) and Tsaknis et al., (1999) they found that the oleic acid in Moringa oil was $70.00 \%, 74.93 \%$ and $73.60 \%$, respectively. who found vaccenic acid was $(6.00 \%)$ in Moringa seeds. Some health benefits for vaccenic acid were reported by Field et al., (2009). Significant difference occurred in myristic and plametic acids between whole seeds and kernels $(0.12-0.15 \%)$ and $(5.55-5.90 \%)$, respectively.

Tocopherols:

Moringa oleifera (whole seeds and kernels ) has a good amount of tocopherols and this give more protection and stability during storage and manufacturing processes for Moringa oil (Tsaknis et al., 1999). The kernels had more amounts of tocopherols by hot extraction than the whole seeds $20.92-14.61 \mathrm{mg} / 100 \mathrm{~g} \alpha$-tocopherol, $1.01-$ 
$0.94 \mathrm{mg} / 100 \mathrm{~g} \beta$-tocopherol, $5.77-5.31 \mathrm{mg} / 100 \mathrm{~g} \gamma$ tocopherol and $1.10-1.01 \mathrm{mg} / 100 \mathrm{~g} \delta$ - tocopherol, respectively (Table 4).

Almost these results were near to Rahman et al., (2009) who used light petroleum ether for extracting the oil form the Moringa kernels and found that $\alpha$-tocopherol, $\gamma$ tocopherol and $\delta$ - tocopherol were $12.1,6.4,5.77 \mathrm{mg} / 100 \mathrm{~g}$, respectively. Also, Anwar and Bhanger, (2003) determined $\alpha$-tocopherol, $\gamma$-tocopherol and $\delta$ - tocopherol from Moringa kernels but they used $n$-hexane and they found the results were $13.44,9.37$ and $4.80 \mathrm{mg} / 100 \mathrm{~g}$, respectively. However, from whole seeds and by using n-hexane, Tsaknis et al., (1999) reported that $\alpha$-tocopherol, $\gamma$-tocopherol and $\delta$ tocopherol were $(9.82,2.79$ and $7.11 \mathrm{mg} / \mathrm{kg})$, respectively.

Table 4. Tocopherols composition of Moringa oleifera (whole seeds and kernels) by hot and cold extraction mg/100g:

\begin{tabular}{|c|c|c|c|c|}
\hline \multirow{3}{*}{ Tocopherols } & \multicolumn{2}{|c|}{ Moringa oleifera } & \multicolumn{2}{|c|}{ Moringa oleifera } \\
\hline & \multicolumn{2}{|c|}{ Whole seeds } & \multicolumn{2}{|c|}{ Kernels } \\
\hline & Hot & Cold & Hot & Cold \\
\hline$\overline{\alpha \text {-Tocopherol }}$ & $14.61 \pm 1.497 *$ & $14.15 \pm 0.035$ & $20.92 \pm 0.710^{* \mathrm{~b}}$ & $16.82 \pm 0.840^{6}$ \\
\hline$\alpha$-Tocotrienol & $0.18 \pm 0.015^{*}$ & $0.37 \pm 0.120$ & $0.22 \pm 0.029 *$ & $0.27 \pm 0.44$ \\
\hline$\beta$-Tocopherol & $0.94 \pm 0.076$ & $0.77 \pm 0.031$ & $1.01 \pm 0.035$ & $0.85 \pm 0.067$ \\
\hline$\gamma$-Tocopherol & $5.31 \pm 0.235^{\mathrm{a}}$ & $3.35 \pm 0.171^{\mathrm{a}}$ & $5.77 \pm 0.278^{\mathrm{b}}$ & $4.27 \pm 0.578^{\mathrm{b}}$ \\
\hline Plastochromanol 8 & $0.20 \pm 0.171^{\mathrm{a}}$ & $0.91 \pm 0.015^{\mathrm{a}}$ & $0.25 \pm 0.223^{\mathrm{b}}$ & $1.05 \pm 0.265^{\mathrm{b}}$ \\
\hline$\delta$ - Tocopherol & $1.01 \pm 0.092^{\mathrm{a}}$ & $0.41 \pm 0.065^{\mathrm{a}}$ & $1.10 \pm 0.174$ & $0.52 \pm 0.035^{\mathrm{b}}$ \\
\hline
\end{tabular}

(*) Means that there are significant differences between whole seeds and kernels (hot extraction) at $\leq 0.05$.

(a) Means that there are significant differences between whole seeds (hot and cold extraction) at $\leq 0.05$.

(b) Means that there are significant differences between kernels (hot and cold extraction) at $\leq 0.05$.

The results of $\gamma$-Tocopherol, Plastochromanol 8 (Plastochromanol- 8 is an analogue of $\gamma$-tocotrienol with a much longer side-chain). Plastochromanol-8 was first found in leaves of the rubber tree (Hevea brasiliensis) from 50 years ago (Whittle et al., 1965). It has been found in many other plants including rapeseed and maize (Dunphy et al., 1966), but usually at lower levels than of the tocopherols) and $\delta$ - tocopherol in whole seeds and kernels after cold extraction changed. Data in Table (4) indicated that a decreasing happened to $\gamma$-tocopherol and $\delta$ - tocopherol in whole seeds and kernels $(5.31-3.35 \mathrm{mg} / 100 \mathrm{~g}),(5.77-4.27$ $\mathrm{mg} / 100 \mathrm{~g})$ and $(1.01-0.41 \mathrm{mg} / 100 \mathrm{~g}),(1.10-0.52$ $\mathrm{mg} / 100 \mathrm{~g})$, respectively, while plastochromanol 8 increased in cold extraction $(0.91-0.1 .05 \mathrm{mg} / 100 \mathrm{~g})$ than hot extraction $(0.20-0.25 \mathrm{mg} / 100 \mathrm{~g})$, respectively. No significant differences occurred in $\alpha$-tocopherol between hot and cold extraction of the whole seeds, while in the kernels a differences occurred in $\alpha$-tocopherol (20.92 - 16.82 $\mathrm{mg} / 100 \mathrm{~g}$ ) in hot and cold extraction, respectively (Table 4).

Triglycerides profile:

As shown in the Table (5) eleven triglycerides were detected in the order of (OOO, POO, SLO, SOO, PLS, PLO,
LLL, POS, POP, SOS and PLP) $(\mathrm{O}=$ oleic acid, $\mathrm{L}=$ linoleic acid, $\mathrm{P}=$ palmitic acid and $\mathrm{S}=$ stearic acid). and those accounts for $85 \%$ of total triglycerides. The highest triglyceride was (OOO) in the whole seeds and kernels $(34.22-34.32 \%)$ followed by "POO" (15.64 - 15.86\%), "SLO" (10.25 - 10.45\%) and "SOO" (9.82 - 9.86\%). A difference occurred in the triglycerides "POO" and "OOO" between whole seeds and kernels. These results were near to Abdulkarim et al., (2005) who reported that "OOO" and "SOO" were $(36.70-11.40 \%)$ in the whole seeds.

Using cold extraction (whole seeds) made a difference in the triglycerides "SOS" and "SOO" (1.77 $2.17 \%)$ and $(9.82-11.25 \%)$, respectively. This increase may be due to the increase of stearic acid in the whole seeds after cold extraction (4.55 - 5.51\%). Also, due to the increase reported in stearic acid after cold extraction in kernels , the triglycerides "POS" and "SOO" increased $(2.07-2.32 \%)$ and $(9.87-11.38 \%)$, respectively. However the decreasing occurred in "PLP" $(1.38-0.83 \%)$ was due to the decrease in palmitic acids after cold extraction in the kernels $(5.90-5.16 \%)$.

Table 5. Triglycerides profile of Moringa oleifera (whole seeds and kernels) by hot and cold extraction (\%):

\begin{tabular}{lcccc}
\hline \multirow{2}{*}{ Triglycerides } & \multicolumn{4}{c}{ Moringa oleifera } \\
\cline { 2 - 5 } & Hot & Cold & Hot & Cold \\
\cline { 2 - 5 } & $1.79 \pm 0.167$ & $1.51 \pm 0.035$ & $1.92 \pm 0.140$ & $1.64 \pm 0.167$ \\
POP & $1.03 \pm 0.302$ & $0.74 \pm 0.035$ & $1.38 \pm 0.020^{\mathrm{b}}$ & $0.83 \pm 0.056^{\mathrm{b}}$ \\
PLP & $2.05 \pm 0.139$ & $2.30 \pm 0.035$ & $2.07 \pm 0.126^{\mathrm{b}}$ & $2.32 \pm 0.113^{\mathrm{b}}$ \\
POS & $15.64 \pm 1.311^{*}$ & $14.50 \pm 0.349$ & $15.86 \pm 1.316^{*}$ & $14.73 \pm 0.936$ \\
POO & $2.94 \pm 0.132$ & $2.83 \pm 0.353$ & $3.05 \pm 0.102$ & $2.85 \pm 0.120$ \\
PLS & $2.88 \pm 0.373$ & $3.05 \pm 0.383$ & $2.95 \pm 0.373$ & $2.83 \pm 0.317$ \\
PLO & $1.77 \pm 0.075^{\mathrm{a}}$ & $2.17 \pm 0.045^{\mathrm{a}}$ & $1.80 \pm 0.095$ & $2.07 \pm 0.060$ \\
SOS & $9.82 \pm 0.389^{\mathrm{a}}$ & $11.25 \pm 0.120^{\mathrm{a}}$ & $9.86 \pm 0.260^{\mathrm{b}}$ & $11.38 \pm 0.236^{\mathrm{b}}$ \\
SOO & $34.22 \pm 1.038^{*}$ & $34.81 \pm 0.467$ & $34.32 \pm 1.059^{*}$ & $33.75 \pm 0.906$ \\
OOO & $10.25 \pm 0.616$ & $10.16 \pm 1.141$ & $10.45 \pm 0.595$ & $9.42 \pm 0.310$ \\
SLO & $2.21 \pm 0.046$ & $2.38 \pm 0.122$ & $2.22 \pm 0.095$ & $2.25 \pm 0.070$ \\
LLL & 15.40 & 14.30 & 14.12 & 15.93 \\
Others & POS & &
\end{tabular}

POP, 1,3-dipalmitoyl-2-oleylglycerol; PLP, 1,3-dipalmitoyl-2-linoleylglycerol; POS: palmitoyl-oleoyl-stearoyl glycerol; POO, 2,3-dioleyl-1palmitoylglycerol; PLS,1-palmitoyl-2-linoley-3-stearoylglycerol; PLO: 1-palmitoyl-2-linoleoyl-3-oleoylglycerol; SOS, 1,3-distearoyl-2oleylglycerol; SOO, 2,3-dioleyl-1- stearoylglycerol; OOO, 1,2,3 trioleylglycerol; SLO 1-stearoyl-2-linoleyl-3- oleoylglycerol and LLL, 1,2,3trilinoleylglycerol.

(*) Means significant differences between whole seeds and kernels (hot extraction) at $\leq 0.05$.

(a) Means significant differences between whole seeds (hot and cold extraction) at $\leq 0.05$.

(b) Means significant differences between kernels (hot and cold extraction) at $\leq \mathbf{0 . 0 5}$. 


\section{CONCLUSION}

Removing the coat from the whole seeds and extracting oil from the kernels increased the oil amount. This coat can be used in several uses. Cold extraction method caused an increase in the TSFA in the whole seeds and kernels, while the TUSFA decreased in both. Tocopherols were higher in the kernels oil than the whole seeds oil but cold extraction caused a decrease in tocopherol in both. Also, triolien "OOO" and "POO" were higher in the kernels oil. Due to the increase of stearic acid after cold extraction in whole seeds and kernels this makes an increase in the triglycerides "SOO and SOS".

\section{REFERENCES}

Abdulkarim, S. M.; Long, K.; Lai, O. M.; Muhammad, S. K. S. and Ghazali , H.M. (2005). Some physicochemical properties of Moringa oleifera seed oil extracted using solvent and aqueous enzymatic methods. Food Chemistry 93, 253-263.

Abdulkarim, S. M.; Long, K.; Lai, O. M.; Muhammad S. K. S. and Ghazali H.M. (2007). Frying quality and stability of high-oleic Moringa oleifera seed oil in comparison with other vegetable oils, Food Chem. 105, 1382-1389.

Abiodun O. A.; Adegbite, J. A. and Omolola, A. O. (2012). Chemical and physicochemical properties of moringa flours and oil. Global J. of Sci. Frontier Res. Biological Sci. Vol. 12, Issue 5, Version 1.0, p. 13-17.

Al Juhaimi, F.; Ghafoor, K.; Babiker, E. E.; Matthaus, B. and Ozcan M. M. (2016). The biochemical composition of the leaves and seeds meals of moringa species as non-conventional sources of nutrients. Journal of Food Biochemistry. 00-00.

Amagloh, F. K. and Benang, B. (2009). Effectiveness of Moringa oleifera seed as coagulant for water purification. African. J. Agric. Res., 4 (1): 119- 123.

Anwar, F. and Bhangers, M. I. (2003). Analytical characterization of Moringa oleifera seed oil grown in temperate regions of Pakistan. J. Agric. Food Chem. 51, 6558-6563.

Anwar, F.; Latif, S.; Ashraf, M. and Gilani, A.H. (2007). Moringa oleifera: a food plant with multiple biochemical and medicinal uses- a review. Phytother. Res., 21: 17-25.

Anwar F. and Rashid, U. (2007). Physico-chemical charactereistics of Moringa oleifera seeds and seed oil from oil from a wild provenance of Pakistan. Pak. J. Bot., 39(5): 1443-1453.

Banov, D.; Banov, F., and Bassani, A. S. (2014). Case Series: The effectiveness of fatty acids from pracaxi oil in a topical silicone base for scar and wound therapy. Dermatology and Therapy, 4, 259-269.

Bhutada, P. R.; Jadhav, A. J.; Pinjari, D. V. and Nemade, P. R. (2016). Solvent assisted extraction of oil from Moringa oleifera Lam. seeds. Industrial Crops and Products 82, 74-80.

Cáceres, A.; Saravia, A.; Rizzo, S.; Zabala, L.; De Leon, E. and Nave, F. (1992). Pharamacologic properties of Moringa oleifera: 2: Screening for antispasmodic, anti-inflammatoryand diuretic activity. J. Ethnopharmacol. 36 (3), 233-237.
Compaoré, W.R.; Nikièma,P.A.; Bassolé, H.I.N.A.; Savadogo, A.; Mouecoucou,J.; Hounhouigan D.J. and Traoré , S.A. (2011). Chemical composition and antioxidative properties of seeds of Moringa oleifera and pulps of parkia biglobosa and adansonia digitata commonly used in food fortification in Burkina Faso. Research Journal of Biological Sciences 3(1): 64-72.

Da Porto, C.; Decorti, D. and Natolino, A. (2016). Microwave pretreatment of Moringa oleifera seed: Effect on oil obtained by pilot-scale supercritical carbon dioxide extraction and Soxhlet apparatus. J. of Supercritical Fluids 107, 38-43.

Dahot, M. U. and Memon, A. R. (1985). Nutritive significance of oil extracted from Moringa oleifera seeds. Journal of Pharmacology (University of Karachi), 20, 75-79.

Deutsche Gesellschaft für Fettwissenschaften E. V. (2013). Deutsche einheitsmethoden zur untersuchung von fetten, fettprodukten, tensiden und verwandten stoffen, wissenschaftliche verlagsgesellschaft, Stuttgart.

Dunphy, P.J., Whittle, K.J., and Pennock, J.F. (1966). Plastochromanol. In: Goodwin, T.W. (Ed.), Biochemistry of Chloroplasts. Academic Press, London, pp. 165-171.

Field, C. J.; Blewett, H. H.; Proctor, S., and Vine, D. (2009). Human health benefits of vaccenic acid. Applied Physiology Nutrition and Metabolism, 34, 979-991.

Gowrishankar, R.; Kumar, M.; Menon, V.; Divi, S.M.; Saravanan, M.; Magudapathy, P.; Panigrahi, B.K.; Nair, K.G. and Venkataramaniah, K. (2010). Trace element studies on Tinospora cordifolia (menispermaceae), Ocimum sanctum (lamiaceae), Moringa oleifera (moringaceae), and Phyllanthus niruri (euphorbiaceae) using PIXE. Biological Trace Element Research. 133(3):357-363.

Ibrahim, S. S.; Ismail, M.; Samuel, G.; Kamel, E. and El Azhari, T. (1974). Benseeds: A Potential Oil Source. Agric. Res. Rev. 52, 47-50.

Jahn, S.A.A., (1988). Using moringa seeds as coagulants in developing countries. Journal of American Water Works Association., 80:43-50.

Kalogo, Y.; Rosillon F.; Hammes F. and Verstraete W. (2000). Effect of a water extract of Moringa oleifera seeds on the hydrolytic microbial species diversity of a UASB reactor treating domestic wastewater. Letters in Appl. Microbio., 31: 259-264.

Kibazohi, O. and Sangwan, R. S. (2011). Vegetable oil production potential from Jatropha curcas, Croton megalocarpus, Aleurites moluccana, Moringa oleifera and Pachira glabra: Assessment of renewable energy resources for bio-energy production in Africa. Biomass and Bioenergy 35, 1352-1356.

Kleiman, R.; Ashley, D. A. and Brown, J.H. (2008). Short communication - comparison of two seed oils used in cosmetics, moringa and marula, Ind. Crop. Product. 28, 361-364.

Marrufo, T.; Nazzaro, F.; Mancini, E.; Fratianni, F.; Coppola, R.; De Martino, L.; Agostinho, A. B. and De Feo, V. (2013). Chemical composition and biological activity of the essential oil from leaves of Moringa oleifera Lam. cultivated in Mozambique. Molecules 18, 10989-11000. 
Morimitsu, Y.; Hayashi, K.; Nakagama, Y.; Horio, F.; Uchida,K. andOsawa, T. (2000). Antiplatelet and anticancer isothiocyanates inJapanese horseradish, wasabi. BioFactors 13 (1-4), 271-276.

Morton, J. F. (1991). The Horse radish tree, Moringapterygosperma. A boon to arid lands. Economic Botany, 45, 318-333.

Mughal, M. H.; Ali, G.; Srivastava, P. S. and Iqbal, M. (1999). Improvement of drumstick (Moringapterygosperms Gaertn.)sa unique source of food and medicine through tissue culture. Hamdard Med. 42 (1), 37-42.

Nguyen, H. N., Gaspillo, P. D., Maridable, J. B., Malaluan, R. M., Hinodec, H., Salim, C., and Huynh, H. K. P. (2011). Extraction of oil from Moringa oleifera kernels using supercritical carbon dioxide with ethanol for pretreatment: Optimization of the extraction process. Chemical Engineering and Processing, 50, 1207-1213

Nzikou J. M.; Matos, L.; Moussounga, J. E.; Ndangui, C. B.; Kimbonguila, A. Silou, Th.; Linder, M. and Desobry, S. (2009). Characterization of Moringa oleifera seed oil variety Congo-Brazzaville. J. of Food Technology 7 (3): 59-65.

Oduro I.; Ellis W. O. and Owusu D. (2008). Nutritional potential of two leafy vegetables: Moringa oleifera and Ipomoea batatas leaves. Scientific Research and Essay Vol. 3 (2), pp. 057-060.

Okereke, C. J., and Akaninwor, J. O. (2013). The protein quality of raw leaf, seed and root of Moringa oleifera grown in Rivers State, Nigeria. Annals of Biological Research, 4, 34-38

Petukhov, I.; Malcolmson, L. J.; Przybylski, R., and Armstrong, L. (1999). Frying performance of genetically modified Canola oils. Journal of the American Oil Chemists Society, 76, 627-632.

Qaiser, M. (1973). Moringaceae. In Flora of West Pakistan, No. 38; Nasir, E., Ali, S. I., Eds.; Department of Botany, University of Karachi: Karachi, Pakistan, pp $1-4$.
Rahman I. M.M.; Barua S.; Nazimuddin, M.; Begum Z. A.; Rahman M. A. and Hasegawa H. (2009). Physiochemical properties of Moringa oleifera lam. Seed oil of the indigenous-cultivar of Bangladesh.

Rashid, U.; Anwar, F.; Moser, B. R., and Knothe, G. (2008). Moringa oleifera oil: A possible source of biodiesel. Bioresource Technology, 99, 8175-8179.

Siddhuraju, P. and Becker, K. (2003). Antioxidant properties of various solvent extracts of total phenolic constituents from three different agroclimatic origins of drumstick tree (Moringa oleifera Lam). J. Agric. Food Chem. 15, 2144-2155.

Singh, K. K. and Kumar, K. (1999). Ethnotherapeutics of some medicinal plants used as antipyretic agent among the tribals of India. J. Econ. Taxon. Bot. 23 (1), 135-141.

Sodamade, A.; Bolaji, O. S. and Adeboye, O. O. (2013). Proximate analysis, mineral contents and functional properties of Moringa oleifera leaf protein concentrate. Journal of Applied Chemistry. V. 4, Issue 6 (May. - Jun.), 47-51.

Steel, R.G. and Torrie, J.H. (1980). Principles and procedures of Statistics. London: McGraw Hill.

The Australian New Crops Newsletter (TANCN) (2003). htttp://www.newcrops. uq.edu.au/newalett/ncn19192.

The Wealth of India (1962). (A Dictionary of Indian Raw Materials and Industrial Products); Raw Materials, Vol. VI, L-M; Council of Scientific and Industrial Research: New Delhi, India, pp 425-429.

Tsaknis, J.; Lalas, S.; Gergis, V.; Dourtoglou, V. and Spiliotis, V. (1999). Characterization of Moringa oleifera variety Mbololo seed oil of Kenya. J. Agric.Food Chem., 47, 4495-4499.

Von M (1986). Trees and Shrubs of the Sahal. Their Characteristics and Uses, Deutsche Gesellschaft fur Technische Zusammenarbeit.1986; 334-37.

Whittle, K.J., Dunphy, P.J. and Pennock, J.F., (1965). Plastochromanol in the leaves of Hevea brasiliensis. Biochem. J. 96, 17-19.

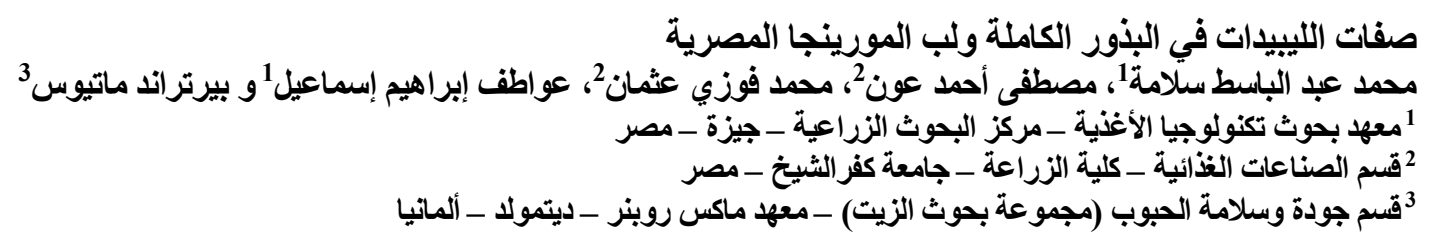

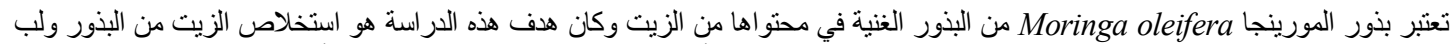

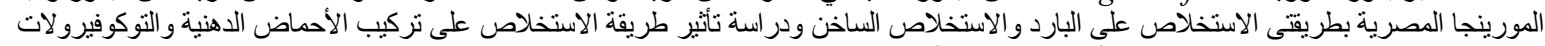

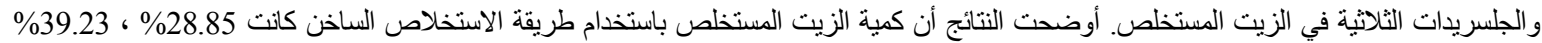

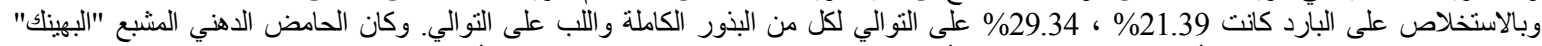

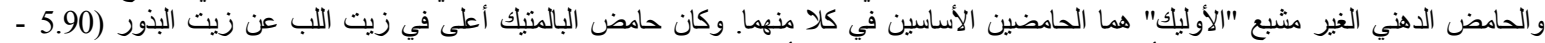

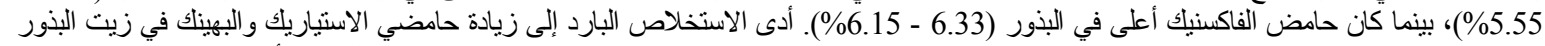

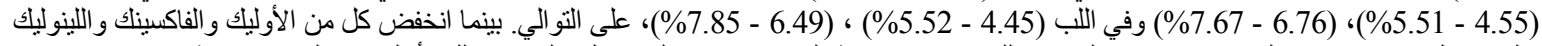
و الجوندويك بالاستخلاص البارد في كلا من البذور و اللب.

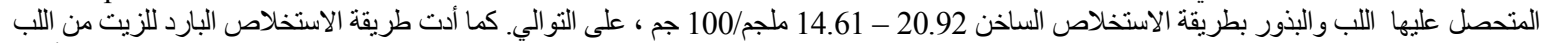

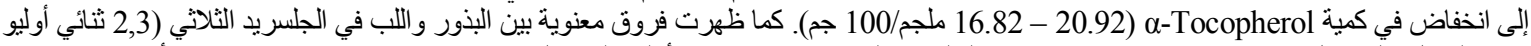

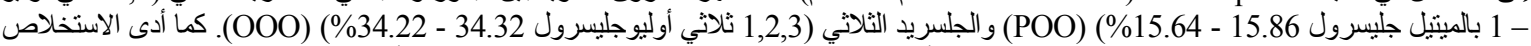

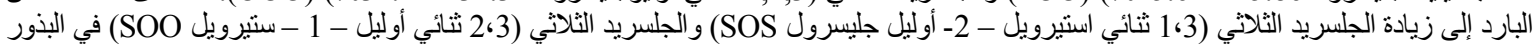

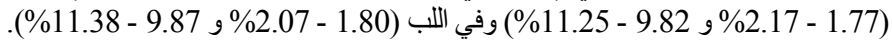

